九州大学学術情報リポジトリ

Kyushu University Institutional Repository

Preliminary trials of Genotype-by-Environment Interactions for Sugars, Organic Acids, and Amino Acids of Table Grape Varieties in Japan

Shiraishi, Mikio

Fruit Science Laboratory, Faculty of Agriculture, Kyushu University

Shiraishi, Shin-ichi

Fruit Science Laboratory, Faculty of Agriculture, Kyushu University

https://doi.org/10.5109/24141

出版情報：九州大学大学院農学研究院紀要. 41 (3/4)，pp.157-163，1997-03. Kyushu University バージョン：

権利関係 : 


\title{
Preliminary trials of Genotype-by-Environment Interactions for Sugars, Organic Acids, and Amino Acids of Table Grape Varieties in Japan
}

\author{
Mikio Shiraishi* and Shin-ichi Shiraishi
}

\author{
Fruit Science Laboratory, Faculty of Agriculture, Kyushu University, \\ Fukuoka 81 1-23, Japan \\ (Received November 11, 1996; Accepted December 17,1996)
}

\begin{abstract}
For the period of two successive years, biochemical quality traits of four table grape varieties were evaluated at the eight locations in southwestern part of Japan, especially in Kyushu district. Of quality traits considered, Brix, reducing sugar content, a ratio, free acid content, $\beta$ ratio, amino acid content, and $\gamma$ ratio were determined on all grape berries tested. By two techniques (I: coefficient of variability, CV and II : analyses of variance), genotype-byenvironment interaction was large in sugar content, free acid content, acid composition ( $\beta$ ratio), and amino acids. There was no significant difference in the a ratio for location's and year's effects. Furthermore, excepting amino acid content, there were significant varietal differences in the traits examined, indicating that the genotypic effect is not negligible.
\end{abstract}

\section{INTRODUCTION}

For evaluating the potential of varieties or selected lines, a number of trials are generally performed under several environmental conditions over years, locations, and treatments. In such trials, there has frequently found significant genotype-byenvironment interaction of several temperate fruits (Hansche and Beres, 1965; Hansche et al., 1972; Machida and Kozaki, 1975; Yamada et al., 1993). To the grape growers and breeders, it is certainly of value to know the magnitude of stability of quality traits for each genotype and, if possible, to presume genotype-by-environment interactions in response to a number of environment.

With respect to quality traits (especially in biochemical ones), the present trials were performed to compare the nature and magnitude of response of commercial table grape varieties to several different environments encountered in the southwestern part of Japan, especially in Kyushu district.

\section{MATERIALS AND METHODS}

A total of four table grape varieties ('Campbell Early', 'Kyoho', 'Muscat Bailey A', 'Neo Muscat') have been grown by overhead arbor training system at eight locations. These varieties used are cultivated as the leading commercial table grapes in Japan. The eight locations were chosen to cover the different environmental conditions encountered in the grape growing regions in southwestern part of Japan; they were, as shown in Fig.1, Fukuoka- 1 (Kyushu University, Fukuoka Prefecture), Fukuoka-2 (Fukuoka Pref.

* Present address: Minamichikugo Agricultural Extension Center, Fukuoka 835, Setaka, Shimonosho 801-1, Japan. 


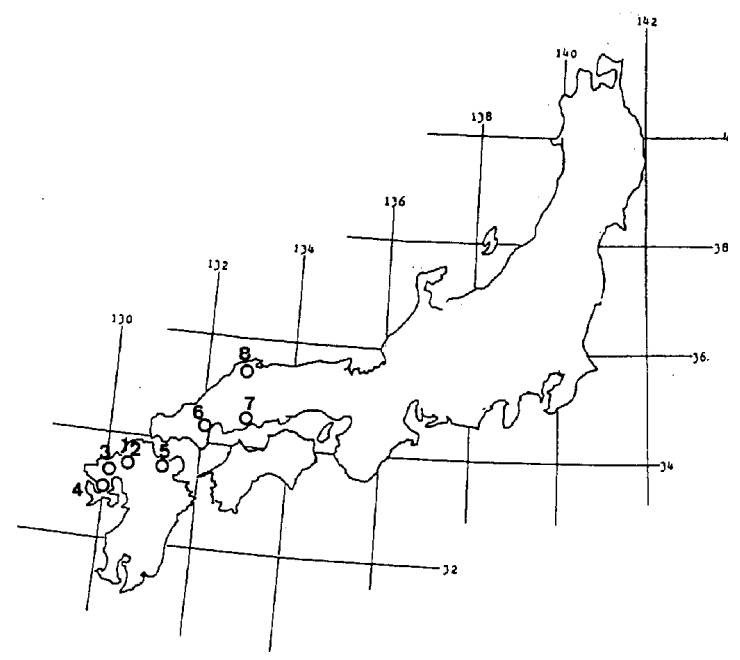

Fig. 1. Location of experimental stations.

The numerals given to the points indicate the locations listed in Table 1-3.
1. Fukuoka-1 2. Fukuoka-2 3. Saga
4. Nagasaki
5. Oita
6. Hiroshima 7. Okayama 8. Shimane

Agricultural Research Center), Saga (Saga Pref. Fruit Tree Research Station), Nagasaki (Nagasaki Pref. Fruit Tree Research Station), Oita (Oita Pref. Agricultural Research Center), Hiroshima (Akitsu Branch, Fruit Tree Research Station), Okayama (Okayama Pref. Agricultural Research Station), and Shimane (Shimane Pref. Agricultural Research Station). For two successive years, 1992-1993, two vigorous vines per variety were used for analyses of sugars, organic acids, and amino acids. Determination of sugars (Brix, reducing sugar content, and $\alpha$ ratio: Shiraishi, 1993), organic acids (free acid content, and $\beta$ ratio: Shiraishi, 1995), and amino acids (ammo acid content, and $\gamma$ ratio: Shiraishi, 1996) was performed on all berries from two clusters per vine.

\section{RESULTS}

In these trials, all observations on all grape varieties over all years and locations could not be obtained due to climatic conditions, in particular, heavy rainfall at fruit maturity. For each of the varieties, mean and coefficient of variability $(\mathrm{CV} \%)$ of Brix, reducing sugar content, $\alpha$ ratio, free acid content, $\beta$ ratio, amino acid content, and $\gamma$ ratio are given in Table 1-3. 
Table 1. Environmental variation in sugars of table grape varieties.

\begin{tabular}{|c|c|c|c|c|c|c|c|c|}
\hline \multirow[t]{2}{*}{ Location } & \multicolumn{2}{|c|}{ Kyoho } & \multirow{2}{*}{$\begin{array}{c}\text { Muscat } \\
1992\end{array}$} & \multirow{2}{*}{$\frac{\text { Bailey A }}{1993}$} & \multirow{2}{*}{$\frac{\text { Campbel }}{1992}$} & \multirow{2}{*}{$\frac{\text { Early }}{1993}$} & \multirow{2}{*}{$\frac{\mathrm{Ne} 0}{1992}$} & \multirow{2}{*}{$\begin{array}{r}\text { Muscat } \\
1993\end{array}$} \\
\hline & 1992 & 1993 & & & & & & \\
\hline & \multicolumn{2}{|c|}{$--------+=$} & \multicolumn{4}{|c|}{$---n=--$ Brix (\%) } & \multicolumn{2}{|c|}{ 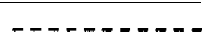 } \\
\hline Fukuoka-1 & 16.1 & 17.0 & 16.0 & 15.9 & 12.7 & 15.6 & 14.7 & 16.1 \\
\hline Fukuoka-2 & 18.4 & 16.5 & 16.8 & 17.3 & 11.6 & 12.8 & 12.2 & 15.1 \\
\hline Saga & 17.6 & 16.1 & & 15.3 & & 13.7 & - & 14.0 \\
\hline Nagasaki & 17.8 & 18.3 & 16.4 & 14.9 & - & & & \\
\hline Oita & 18.2 & 18.0 & 17.8 & 16.7 & 11.2 & 14.1 & 15.3 & 14.4 \\
\hline Hiroshima & 17.7 & - & 16.7 & & 12.7 & & 17.8 & - \\
\hline Okayama & 15.8 & 17.4 & 15.9 & 15.2 & 10.4 & 11.5 & 14.9 & 15.0 \\
\hline Shimane & 17.5 & - & & & & & 16.1 & - \\
\hline mean & \multicolumn{2}{|c|}{$17.3^{\mathrm{d}}$} & \multicolumn{2}{|c|}{$16.2^{\mathrm{c}}$} & \multicolumn{2}{|c|}{$12.6 ”$} & \multicolumn{2}{|c|}{$15.1^{b}$} \\
\hline \multirow[t]{2}{*}{ CV } & \multicolumn{2}{|c|}{$5 \%$} & & $\%$ & \multicolumn{2}{|c|}{$12 \%$} & \multicolumn{2}{|c|}{$9 \%$} \\
\hline & & & \multicolumn{6}{|c|}{ conte } \\
\hline Fukuoka- 1 & 14.8 & 15.0 & 14.4 & 13.5 & 10.5 & 12.8 & 13.8 & 14.2 \\
\hline Fukuoka-2 & 18.0 & 14.7 & 14.3 & 15.0 & 11.5 & 11.1 & 11.0 & 12.6 \\
\hline Saga & 16.7 & 13.5 & & 13.1 & & 11.6 & - & 12.4 \\
\hline Nagasaki & 16.0 & 16.3 & 15.8 & 12.5 & & & & \\
\hline Oita & 16.6 & 14.7 & 16.7 & 14.7 & 10.7 & 12.0 & 15.0 & 12.5 \\
\hline Hiroshima & 17.0 & - & 15.9 & - & 11.9 & - & 16.9 & - \\
\hline Okayama & 14.5 & 15.0 & 15.9 & 13.2 & 9.7 & 9.9 & 13.2 & 13.0 \\
\hline Shimane & 16.8 & - & & & & & 14.8 & \\
\hline mean & \multicolumn{2}{|c|}{15.7} & \multicolumn{2}{|c|}{$14.6^{\circ}$} & \multicolumn{2}{|c|}{$11.2 "$} & \multicolumn{2}{|c|}{$13.6^{b}$} \\
\hline CV & \multicolumn{2}{|c|}{$8 \%$} & \multicolumn{2}{|c|}{$9 \%$} & \multicolumn{2}{|c|}{$\begin{array}{r}9 \% \\
\text { ratio }\end{array}$} & \multicolumn{2}{|c|}{$12 \%$} \\
\hline Fukuoka-1 & 1.10 & 1.04 & 1.04 & 1.09 & 0.91 & 0.92 & 1.18 & 1.16 \\
\hline Fukuoka-2 & 1.13 & 1.17 & 1.09 & 1.08 & 0.91 & 0.94 & 1.05 & 1.15 \\
\hline Saga & 1.11 & 1.10 & & 1.09 & - & 0.92 & - & 1.09 \\
\hline Nagasaki & 1.13 & 1.11 & 1.16 & 1.15 & & & & \\
\hline Oita & 1.19 & 1.12 & 1.19 & 1.10 & 1.00 & 0.96 & 1.13 & 1.08 \\
\hline Hiroshima & 1.13 & - & 1.01 & - & 0.93 & & 1.07 & - \\
\hline Okayama & 1.11 & 1.04 & 0.99 & 1.14 & 0.93 & 0.94 & 1.07 & 1.13 \\
\hline Shimane & 1.12 & - & & & & & 1.11 & $=$ \\
\hline mean & & & & $09^{\prime}$ & & & & $11^{\mathrm{b}}$ \\
\hline CV & & & & $\%$ & & & & $4 \%$ \\
\hline
\end{tabular}

In Table 1, Brix of 'Kyoho' varied from $15.8 \%$ to $18.4 \%$ with average of $17.3 \%$, while that of 'Campbell Early' was low (12.6\%), ranging from $10.4 \%$ to $15.6 \%$. The Brix of 'Muscat Bailey A' (16.2\%, ranging from $14.9 \%$ to $17.8 \%$ ) was higher than that of 'Neo Muscat' (15.1\%, ranging from $12.2 \%$ to $17.8 \%$ ). The $\mathrm{CV}$ of the Brix was medium, ranging from $5 \%$ to $12 \%$. Variation pattern of reducing sugar content was similar to that of the Brix value. The reducing sugar content was the highest in 'Kyoho' $(15.7 \mathrm{~g} / 100 \mathrm{ml})$, whereas it was the lowest in 'Campbell Early' (11.2 g). The reducing sugar content of 'Muscat Bailey A' (14.6 g) was higher than that of 'Neo Muscat' (13.6 g). The CV of the reducing sugar content was medium, ranging from $8 \%$ to $12 \%$. Mean a ratio of 'Kyoho' (1.11) and 'Neo Muscat' (1.11) was higher than that of 'Muscat Bailey A' (1.09). The $\alpha$ 
ratio was the lowest in 'Campbell Early' (0.94), ranging from 0.90 to 1.00 . The CV of the $\alpha$ ratio was very small, ranging from $3 \%$ to $6 \%$.

As shown in Table 2, mean free acid content varied from $0.29 \mathrm{~g} / 100 \mathrm{ml}$ ('Campbell Early', ranging from $0.19 \mathrm{~g}$ to $0.36 \mathrm{~g}$ ) to $0.43 \mathrm{~g}$ ('Muscat Bailey A', ranging from $0.30 \mathrm{~g}$ to $0.66 \mathrm{~g})$. The free acid content of 'Neo Muscat' $(0.38 \mathrm{~g}$, ranging from $0.23 \mathrm{~g}$ to $0.53 \mathrm{~g}$ ) was higher than that of 'Kyoho' ( $0.33 \mathrm{~g}$, ranging from $0.24 \mathrm{~g}$ to $0.52 \mathrm{~g}$ ). The $\mathrm{CV}$ of the free acid content was very large, ranging from $17 \%$ to $30 \%$. Mean $\beta$ ratio ranged from 0.88 ('Muscat Bailey A', ranging from 0.56 to 1.26) to 1.97 (Campbell Early', ranging from 1.47 to 2.94$)$. The $\beta$ ratio of 'Kyoho' (1.28, ranging from 0.91 to 1.56$)$ was higher than that of 'Neo Muscat' ( 0.98 , ranging from 0.75 to 1.20$)$. The $\mathrm{CV}$ of $\mathrm{b}$ ratio was large, ranging from $13 \%$ to $24 \%$.

As shown in Table 3, amino acid content varied from $1.29 \mathrm{mmol} / 100 \mathrm{ml}$ ('Muscat Bailey A', ranging from $0.95 \mathrm{mmol}$ to $1.70 \mathrm{mmol}$ ) to $1.39 \mathrm{mmol}$ ('Kyoho', ranging from $1.04 \mathrm{mmol}$ to $1.70 \mathrm{mmol}$ ). Both 'Campbell Early' (ranging from $1.00 \mathrm{mmol}$ to $1.76 \mathrm{mmol}$ ) and 'Neo Muscat' (ranging from $1.09 \mathrm{mmol}$ to $1.79 \mathrm{mmol}$ ) was similar in mean ammo acid content $(1.32 \mathrm{mmol})$. The $\mathrm{CV}$ of the ammo acid content was large, ranging from $16 \%$ to $18 \%$. Mean $\gamma$ ratio varied from 1.02 ('Neo Muscat', ranging from 0.79 to 1.36 ) to 2.47 ('Campbell Early', ranging from 1.58 to 3.09). The $\gamma$ ratio of 'Kyoho' (1.53, ranging from

Table 2. Environmental variation in organic acids of table grape varieties.

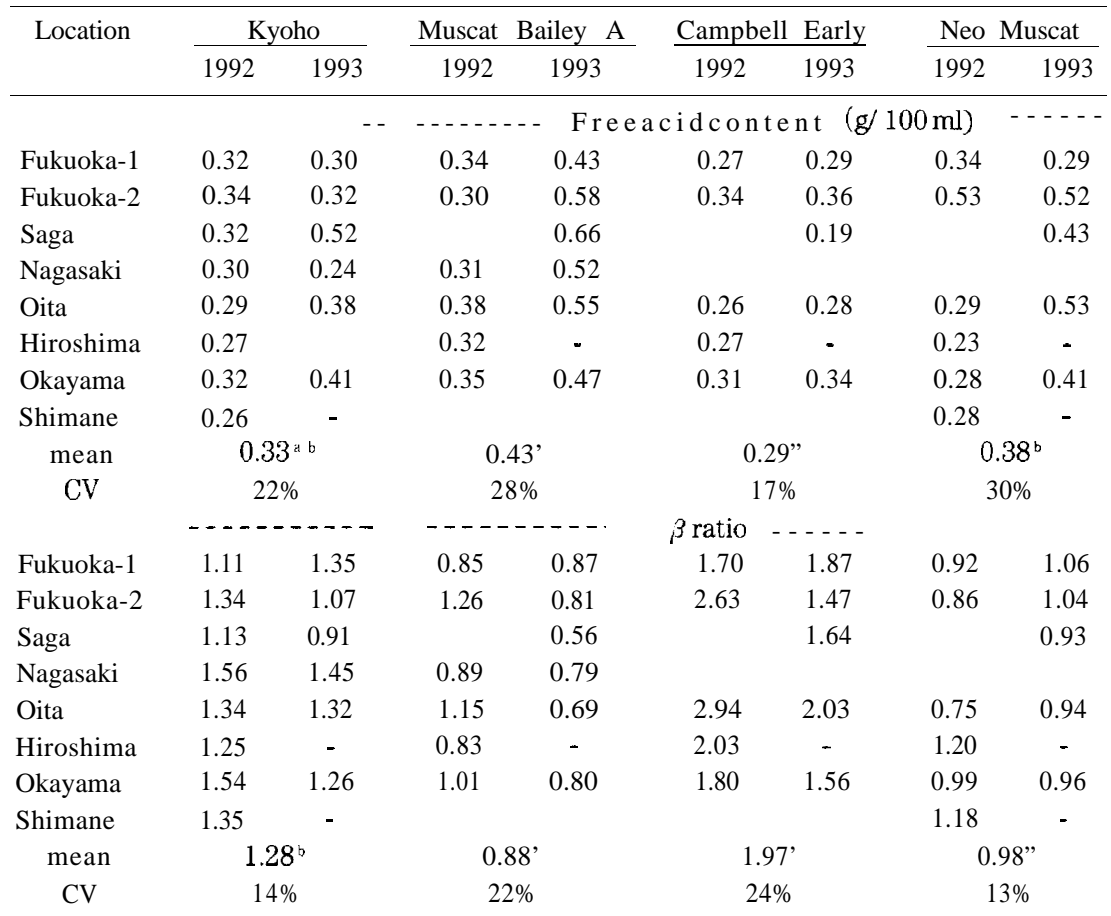


Table 3. Environmental variation in amino acids of table grape varieties.

\begin{tabular}{|c|c|c|c|c|c|c|c|c|}
\hline \multirow[t]{2}{*}{ Location } & \multicolumn{2}{|c|}{ Kyoho } & \multicolumn{2}{|c|}{ Muscat Bailey A } & \multicolumn{2}{|c|}{ Campbell Early } & \multicolumn{2}{|c|}{ Neo Muscat } \\
\hline & 1992 & 1993 & 1992 & 1993 & 1992 & 1993 & 1992 & 1993 \\
\hline & & & $-\ldots$ & \multicolumn{4}{|c|}{ Aminoacid content $(\mathrm{mmol} / 100 \mathrm{ml})$} & $\cdots-\cdots$ \\
\hline Fukuoka- 1 & 1.54 & 1.12 & 1.23 & 1.10 & 1.14 & 1.20 & 1.79 & 1.14 \\
\hline Fukuoka-2 & 1.06 & 1.16 & 1.28 & 1.65 & 1.49 & 1.20 & 1.26 & 1.49 \\
\hline Saga & 1.51 & 1.04 & - & 1.26 & & 1.00 & - & 1.09 \\
\hline Nagasa & 1.70 & 1.42 & 1.70 & 1.42 & - & & & \\
\hline Oita & 1.48 & 1.67 & 1.13 & 1.40 & 1.15 & 1.51 & 1.29 & 1.11 \\
\hline Hiroshima & 1.40 & - & 1.05 & & 1.51 & & 1.59 & - \\
\hline Okayam & 1.31 & 1.49 & 1.25 & 0.95 & 1.76 & 1.24 & 1.28 & 1.01 \\
\hline Shimane & \multirow{2}{*}{\multicolumn{2}{|c|}{ 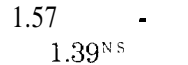 }} & \multirow{2}{*}{\multicolumn{2}{|c|}{$129^{\mathrm{NS}}$}} & & & 1.43 & - \\
\hline mean & & & & & \multicolumn{2}{|c|}{$1.32 " ”$} & \multicolumn{2}{|c|}{$1.32^{\mathrm{Ns}}$} \\
\hline \multirow[t]{2}{*}{$\mathrm{CV}$} & \multicolumn{2}{|c|}{$16 \%$} & \multicolumn{2}{|c|}{$18 \%$} & \multicolumn{2}{|c|}{$18 \%$} & \multicolumn{2}{|c|}{$18 \%$} \\
\hline & & & & & $\begin{array}{c}\gamma \text { ratio } \\
2.54\end{array}$ & & & 0.91 \\
\hline Fukuoka-2 & 1.62 & 1.57 & 1.27 & 1.23 & 2.92 & 3.09 & 1.36 & 1.15 \\
\hline Saga & 1.45 & 1.38 & - & 1.26 & - & 2.13 & - & 1.03 \\
\hline Nagasaki & 1.28 & 1.75 & 1.00 & 1.29 & - & - & & \\
\hline Oita & 1.33 & 1.74 & 1.11 & 1.33 & 1.58 & 2.72 & 0.96 & 0.94 \\
\hline Hiroshima & 1.61 & - & 1.28 & - & 1.75 & - & 0.79 & \\
\hline Okayam & 1.21 & 1.63 & 1.12 & 0.99 & 2.91 & 3.00 & 1.12 & 0.81 \\
\hline Shimane & 1.78 & & & & & & 0.87 & - \\
\hline mean & & & & & & & & 2 \\
\hline $\mathrm{CV}$ & & & & & & & 18 & $\%$ \\
\hline
\end{tabular}

1.21 to 1.75 ) was higher than that of 'Muscat Bailey A' (1.16, ranging from 0.96 to 1.33). The $\mathrm{CV}$ of $\mathbf{y}$ ratio was slightly large, ranging from $11 \%$ to $22 \%$.

To estimate genotype(variety)-by-environment interactions, the data of four varieties on four locations (Fukuoka-1, Fukuoka-2, Oita, and Okayama) over two years were applied to the analysis of variance in the following model:

$$
\begin{aligned}
& \mathrm{X}_{i j k m}=\mu+\mathrm{v}_{i}+\mathrm{l},+\mathrm{y}_{k}+\mathrm{r}_{m}+(\mathrm{vl})_{i j}+(\mathrm{vy})_{i k}+(\mathrm{ly})_{j k}+(\mathrm{vly})_{i j k}+\mathrm{e}_{i j k m} \\
& \text { where } \mathrm{X}_{i j k m}, \mu, \mathrm{v}_{i}, \mathrm{y}_{k}, \mathrm{r}_{m},(\mathrm{vl})_{i j},(\mathrm{vy})_{i k},(\mathrm{ly})_{j k},(\mathrm{vly})_{i j k}, \mathrm{e}_{j j k m},
\end{aligned}
$$

stands for the $\mathrm{m}$-th observation of the $\mathrm{i}$-th variety in the $\mathrm{j}$-th location from the $\mathrm{k}$-th year, an overall mean, an effect contributed by variety $(i=1 . .4)$, an effect attributed by location $(\mathrm{j}=1 . .4)$, an effect attributed by year $(\mathrm{k}=1,2)$, an effect attributed by replication $(\mathrm{m}=1$, 2), a variety $\times$ location interaction $(V \times L)$, a variety $\times$ year interaction $(V \times Y)$, a location $\times$ year interaction $(\mathrm{L} \times \mathrm{Y})$, variety $\times$ ocation $\times$ year interaction $(\mathrm{V} \times \mathrm{L} \times \mathrm{Y})$, and a random effect, respectively.

Genotype-by-environment interactions for each trait considered are summarized in Table 4. Excepting ammo acid content, there was a $99 \%$ significant varietal difference in Brix, reducing sugar content, $\alpha$ ratio, free acid content, $\beta$ ratio, and $\gamma$ ratio. The effect of $\mathrm{V} \times \mathrm{L}$ interaction was of significance $(\mathrm{p}<0.01)$ for Brix, reducing sugar content, free acid content, $\beta$ ratio, and ammo acid content. The effect of $\mathrm{V} \times \mathrm{Y}$ interaction was of significantce $(\mathrm{p}<0.01)$ for Brix, free acid content, and $\beta$ ratio. There was a significant 
Table 4. Analyses of variance, degree of freedom (DF), and mean squares for quality traits.

\begin{tabular}{|c|c|c|c|c|c|c|c|c|}
\hline Source & DF & Brix & $\begin{array}{l}\text { Reducing sugar } \\
\text { content }\end{array}$ & $\alpha$ ratio & $\begin{array}{r}\text { Free acid } \\
\text { content }\end{array}$ & $\beta$ ratio & $\begin{array}{c}\text { Amino acid } \\
\text { content }\end{array}$ & $\gamma$ ratio \\
\hline Location(L) & 3 & & & & & & & \\
\hline $\operatorname{Year}(\mathrm{Y})$ & 1 & & & & & & & \\
\hline Variety (V) & 3 & 222.17” & $70.63 * *$ & $35.2^{\prime \prime}$ & $47.1^{* *}$ & $97.7^{* *}$ & 1.26 & 587.1" \\
\hline $\mathrm{V} \times \mathrm{L}$ & 9 & $10.25^{* *}$ & $4.42^{* *}$ & 1.57 & $4.71^{* *}$ & $3.85^{* *}$ & $3.55^{* *}$ & $2.48^{*}$ \\
\hline $\mathrm{V} \times \mathrm{Y}$ & 3 & $13.79 * *$ & 1.86 & 0.90 & $15.6 " *$ & $8.79^{* *}$ & 0.35 & $3.566^{\prime}$ \\
\hline $\mathrm{V} \times \mathrm{L} \times \mathrm{Y}$ & 9 & 6.06” & 2.01 & 1.23 & $6.36^{* *}$ & 2.11 & $3.15^{\prime \prime}$ & 1.34 \\
\hline Error & 31 & & & & & & & \\
\hline
\end{tabular}

$*=\mathrm{p}-\mathrm{Co} .05$

$* *=p<0.01$

interaction $(\mathrm{p}<0.01)$ for $\mathrm{V} \times \mathrm{L} \times \mathrm{Y}$ in Brix, free acid content, and amino acid content. Furthermore, a 95\% significant difference was found in the $\gamma$ ratio. These results suggest that genotype-by-environment interaction is particularly large for Brix and free acid content, followed by $\beta$ ratio and amino acid content. There was no significant difference in the a ratio.

\section{DISCUSSION}

From these trials, it is possible to presume the nature and magnitude of response of biochemical quality traits to different environmental conditions. Two techniques were used to evaluate the stability of each quality trait of table grape: one is the calculation of coefficient of variability (CV\%) for the traits considered, and the other the analysis of variance.

Although the number of data used was different, as shown above, both techniques gave almost similar results. A large environmental variability in the sugar content and free acid content in these trials is in agreement with previous studies on grape (Rice, 1974; Fanizza, 1982; Firoozabady and Olmo, 1987; Sato et al., 1993). As reported by Rice (1974), the variation of organic acid composition ( $\beta$ ratio) was large, while that of sugar composition ( $\alpha$ ratio) was much small. Amino acid content was large in environmental variation. Although a 95\% significant difference in the yratio for location's and year's effect was observed, differential responses of the varieties to different environments should be considered in terms of adaptability of grape varieties across the location (CV of 'Kyoho' and 'Muscat Bailey A' are 12\% and 11\%, respectirely while that of 'Campbell Early' and 'Neo Muscat' are $22 \%$ and $18 \%$, respectirely). No significant difference was found in the $\alpha$ ratio, indicating that $\alpha$ ratio might be stable and consistent under different environment. Also, excepting amino acid content, there were significant varietal differences $(p<0.01)$ in the traits considered, indicating that the genotypic effect is not negligible. 


\section{ACKNOWLEDGMENT}

The work reported here was performed with the hearty cooperation of research workers for grape breeding and/or cultivation at above seven locations, without whose constant support this project would have been impossible.

\section{REFERENCES}

Fanizza, G. 1982 Variety $x$ location interaction of some characteristics of table and wine grapes (Vitis vinifera) overhead arbor trained in Apulia. In: University of California, Davis Grape and Wine Centennial Symposium Proceedings. pp 69-71.

Firoozabady, E. and H. P. Olmo 1987 Heritability and correlation studies of certain quantitative traits in table grapes, Vitis spp. Vitis, 26: 132-146

Hansche, P. E. and V. Beres 1965 An analysis of environmental variability in sweet cherry. Proc. Amer. Soc. Hort. Sci., 88: 167-172.

Hansche, P. E., C. U. Hesse and V. Beres 1972 Estimates of genetic and environmental effects on several traits in peach. J Amer. Soc. Hort. Sci., 97: 76-79.

Machida, Y. and I. Kozaki 1975 Quantitative studies on the fruit quality for Japanese pear (Pyrus serotina Rehder) breeding. I. Statistical analyses of cultivar populations. J. Japan Soc. Hod. Sci., $\mathbf{4 4}$ (3): 235240.

Rice, A. C. 1974 Chemistry of winemaking from native American grape varieties. In: Chemistry of Winemaking. pp 88-1 15 American Chemical Society, Washington D. C.

Sato, A., M. Yamada, H. Yamane and N. Hirakawa 1993 Repeatability and environmental variation of fruit traits in seedling population of grapes. Bull. Fruit Tree Res. Stn., 24: 1-11

Yamada, M., H. Yamane, K. Yoshinaga and Y.Ukai 1993 Optimal spatial and temporal repetition of measurements for selection in Japanese persimmon breeding. Hort. Sci. (in press) 